\title{
Karakteristik Roti Komposit Ubi Jalar Ungu dengan Penambahan $\alpha$-amilase dan Glukoamilase
}

\section{Characteristic of Composite Bread with a-Amylase and Glucoamylase}

Endah Wulandari dan Elazmanawati Lembong

Fakultas Teknologi Industri Pertanian Universitas Padjadjaran

J1 Raya Jatinangor KM 21 Jatinangor - Sumedang

Email korespondensi: endah.wulandari@unpad.ac.id

\begin{tabular}{l} 
A R T I C LE IN F O \\
\hline Article history \\
Received: 23 Juni 2016 \\
Accepted: 15 Juli 2016 \\
Available online: Februari 2017 \\
\hline Keywords : \\
a-amylase \\
glucoamylase \\
violet sweet potato
\end{tabular}

Kata kunci :

$\alpha$-amilase

glukoamilase

pasta ubi jalar ungu

\begin{abstract}
Enzymes can improve the process of fermentation in bread making and improve shelflife. Not much is known of how the influence of $\alpha$-amylase and glucoamylase in bread made from purple sweet potato pastaand wheat. This study aims to find how big the a-amylase activity and glucoamylase from yeast Saccharomycopsisfibuligera optimum so that the resulting composite bread purple sweet potato pasta: flour (30:70) with a soft texture and volume development together with the control bread (100\% flour). The research method is descriptive. The resulting composite bread with the addition of $\alpha$-amylase and glucoamylase from yeast $S$. fibuligera of $50 \mathrm{U} / 300 \mathrm{~g}$ flour to produce the volume of development which is still lower than the control bread that is $63 \%$ with $39 \%$ water content, reducing sugar content of $4.5 \%$ and crumb hardness (crumbs) 225.52 gf. The resulting composite bread has a development volume is still low when compared with the control bread but have water content and reducing sugar is higher than the control bread so that the bread composites have softness level almost the same as the control bread.

A B S T R A K

Enzim dapat memperbaiki proses fermentasi pada pembuatan roti dan memperbaiki mutu simpannya. Belum banyak diketahui bagaimana pengaruh $\alpha$ amilase dan glukoamilase pada roti yang terbuat dari imbangan pasta ubi jalar ungu dan terigu. Penelitian ini bertujuan mencari seberapa besar aktivitas $\alpha$ amilase dan glukoamilase dari ragi Saccharomycopsis fibuligera yang optimum sehingga dihasilkan roti kompositpasta ubi jalar ungu : terigu (30:70) dengan tekstur empuk dan volume pengembangan sama dengan roti tawar kontrol $(100 \%$ terigu).Metode penelitian yang dilakukan adalah deskriptif. Roti komposit yang dihasilkan dengan tambahan $\alpha$-amilase dan glukoamilase dari ragi $S$. fibuligerasebesar $50 \mathrm{U} / 300 \mathrm{~g}$ tepung menghasilkan volume pengembangan yang masih rendah dibandingkan roti kontrol yaitu 63\% dengankadar air 39\%, kadar gula pereduksi 4,5\% dan kekerasan crumb(remah) 225,52 gf.Roti komposit yang dihasilkan mempunyai volume pengembangan yang masih rendah jika dibandingkan dengan roti control namun memiliki kadar air dan kadar gula reduksi lebih tinggi dari roti control sehingga roti komposit mempunyai tingkat keempukkan hamper sama dengan roti kontrol.
\end{abstract}

\section{Pendahuluan}

Pembuatan roti dari terigu dan pasta ubi jalar ungu adalah salah satu usaha untuk mengurangi penggunaan gandum di Indonesia. Penggantian terigu dengan pasta ubi jalar ungu dilakukan karena ubi jalar merupakan sumber karbohidrat yang tinggi. Ubijalarkayaakanpati (6,9-30,7\% berdasarkanberatbasah,Tianetal.,1991)danpati merupakanpemanfaatanutamasecaraindustriuntukubijalar .Bentuk granula ubi jalar berupa poligonal atau hampir bulat (Moorthy, 2002). Ukuran granula ubi jalar hampirsamadenganukurangranulasingkongyaitusekitar2$42 \mu \mathrm{m}$ (Moorthy, 2002). Ukuran granula ini mempengaruhi sifat-sifat fungsionalseperti volume pengembangan,kelarutandanketercernaan(Moorthy,2002) .Dari perkembangan sejarah teknologi roti, enzim dan ragi sudah digunakan sejak beberapa ratus tahun yang lalu. Pembuatan roti, tanpa disadari sudah memanfaatkan enzim endogenus dari terigu dan enzim dari ragi untuk 
memperbaiki kualitas roti. Di dalam terigu terkandung berbagai enzim yang sangat tergantung pada beberapa faktor seperti faktor selama produksi, umur panen, dan kondisi penyimpanan. Aktivitas enzim tersebut, misalnya $\alpha$-amilase, akan memengaruhi mutu terigu. Tujuan utama aplikasi enzim amilase adalah memperbaiki proses fermentasi (dough leavening) dalam proses pembuatan roti dan memperbaiki mutu simpannya (keeping quality) dengan mempertahankan kesegaran yang lebih lama. Penambahan glukoamilase dapat meningkatkan terbentuknya glukosa yang lebih cepat dapat dimanfaatkan oleh ragi, sehingga penambahan glukoamilase dapat lebih mengaktifkan ragi dan mempercepat proses fermentasi atau pengembangan adonan (dough leavening) (Antara, 2010).

Penambahan enzim dalam adonan roti komposit ini menyebabkan hidrolisis secara enzimatis yang diharapkan dapat meningkatkan fungsionalitas karbohidrat pada roti. Dalam hal pembuatan roti, gelatinisasi adalah suatu peristiwa yang terjadi selama pemanggangan, sementara selama proses penyimpanan, retrogradasi pati (amilopektin) biasanya diketahui untuk menentukan banyaknya pengerasan (staling) pada roti (Gray \& BeMiller, 2003).

Berdasarkan beberapa keterangan yang telah diungkapkan di atas, maka akan dilakukan penelitian mengenai penentuan $\alpha$-amilase dan glukoamilase dari ragi S. fibuligera pada pembuatan roti pasta ubi jalar ungu dan terigu (30 : 70). Roti tersebut diharapkan memiliki volume pengembangan roti yang besar sama dengan roti kontrol, pori-pori yang seragam, dan tingkat kekerasan crumb yang rendah.

\section{Bahan dan Metode}

Bahan yang digunakan adalah bahan-bahan untuk membuat roti tawar sesuai dengan formulasi dan ekstrak enzim ( $\alpha$-amilase dan glukoamilase) dari S. fibuligera R-64 yang telah dipreparasi di Laboratorium Biokimia Jurusan Kimia FMIPA Unpad. Alat yang digunakan adalah peralatanpengolahan roti dan alat kaca serta instrument untukan alisis

Formulasi Bahan Baku Pembuatan Roti.

Tabel 1. Formulasi Roti Tawar yang Digunakan Pada Percobaan Utama

\begin{tabular}{lc}
\hline \multicolumn{1}{c}{ Komponen } & Jumlah \\
\hline Terigu + pasta ubi jalar ungu $(\mathrm{g})$ & $300(70: 30)$ \\
Gula $(\mathrm{g})$ & 22,7 \\
Garam $(\mathrm{g})$ & 7,5 \\
Ragi Roti Instan $(\mathrm{g})$ & 4,5 \\
Susu Skim Bubuk $(\mathrm{g})$ & 15 \\
Mentega Putih $(\mathrm{g})$ & 15 \\
Air & Secukupnya \\
\hline
\end{tabular}

Roti yang telah dibuat selanjutnya diuji volume pengembangan adonan, volume pengembangan roti, kadar air, kadar gula pereduksi dan kekerasan crumb. Roti tersebut juga dideskripsikan untuk adonan, keseragaman pori dan produk rotinya.

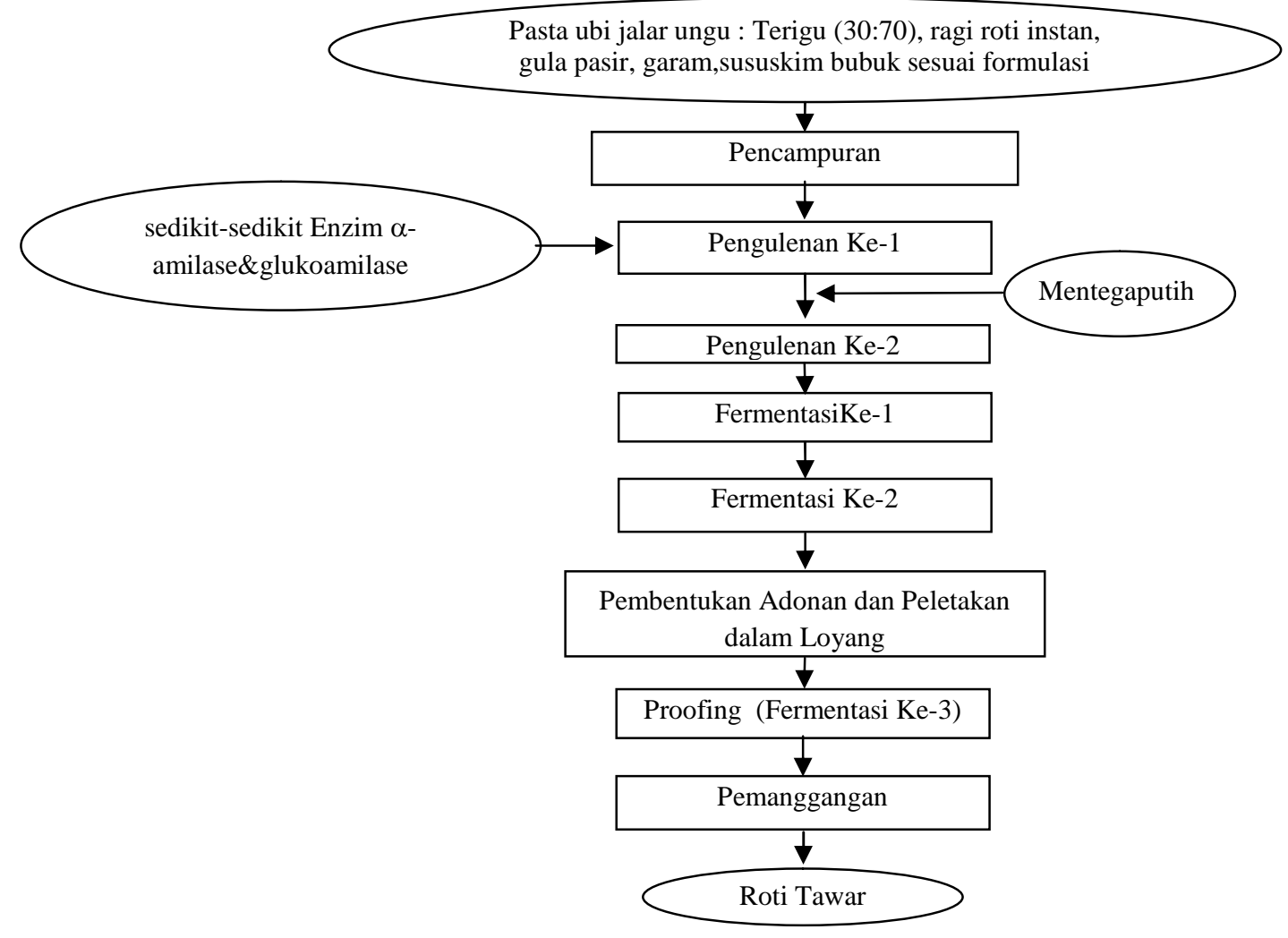

Gambar 1. Diagram Metode Straight Process Cara Lange 


\section{Hasil dan Pembahasan}

\section{Aktivitas $\boldsymbol{\alpha}$-amilase dan Glukoamilase}

Pada penelitian pendahuluan digunakan perbandingan pasta ubi jalar ungu : terigu (30:70) dengan penambahan $\alpha$-amilase dan glukoamilase dari ragi S. fibuligera yaitu $25 \mathrm{U} / \mathrm{g}$ tepung, $50 \mathrm{U} / \mathrm{g}$ tepung dan 75 U/g tepung,. Dari berbagai penambahan $\alpha$-amilase dan glukoamilase menghasilkan adonan yang semakin bertambah tingkat keelastisan dan kehalusannya. Untuk adonan dengan penambahan $\alpha$-amilase dan glukoamilase $25 \mathrm{U} / \mathrm{g}$ tepung masih dihasilkan adonan yang agak kasar sama dengan roti yang terbuat dari pasta ubi jalar ungu : terigu $(30: 70)$ tanpa penambahan enzim. Adonan dengan penambahan $\alpha$-amilase dan glukoamilase $50 \mathrm{U} / \mathrm{g}$ tepung mulai terasa halus dan elastis, tetapi untuk adonan dengan penambahan $\alpha$-amilase dan glukoamilase $75 \mathrm{U} / \mathrm{g}$ tepung mulai terasa lengket.

Roti yang dihasilkan memiliki karakteristik yang lebih padat, elastis, manis dan memiliki aroma khas ragi yang semakin meningkat dengan bertambahnya $\alpha$-amilase dan glukoamilase yang diberikan pada adonan.

Berdasarkan pembahasan di atas maka pada percobaan utama dilakukan penambahan $\alpha$-amilase dan glukoamilase dari ragi $S$. fibuligera dengan aktivitas 25 $\mathrm{U} / \mathrm{g}$ tepung dan50 U/g tepung dengan perbandingan pasta ubi jalar ungu : terigu (30:70).
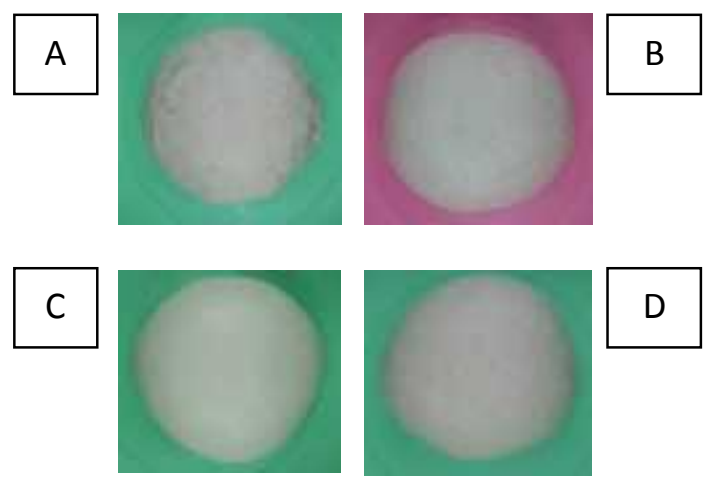

Gambar 2. Adonan-adonan Roti Perlakuan A, B, C, dan D

A: Tanpa penambahan $\alpha$-amilase dan glukoamilase; B: Penambahan $\alpha$-amilase dan glukoamilase dengan aktivitas $25 \mathrm{U} / \mathrm{g}$ tepung; C: Penambahan $\alpha$-amilase dan glukoamilase dengan aktivitas $50 \mathrm{U} / \mathrm{g}$ tepung dan D: Penambahan $\alpha$-amilase dan glukoamilase dengan aktivitas $75 \mathrm{U} / \mathrm{g}$ tepung

Dari Gambar 2 dapat dilihat bahwa semakin tinggi aktivitas $\alpha$-amilase dan Elastisitas adonan tergantung pada tingginya kandungan gluten di dalam adonan. Kandungan gluten dalam adonan roti komposit akan menurun. Elastisitas adonan setelah fermentasi semakin meningkat karena selama fermentasi terjadi pembentukan alkohol dan asam-asam seperti asam cuka oleh bakteri asam asetat dan asam laktat sehingga terjadi penurunan $\mathrm{pH}$ dari 5,3 menjadi 4,5. Penurunan $\mathrm{pH}$ tersebut memengaruhi hidrasi dan gluten menjadi lebih lunak dan elastis (Herschdoerfer, 1986 dikutip Marlon, 1994).

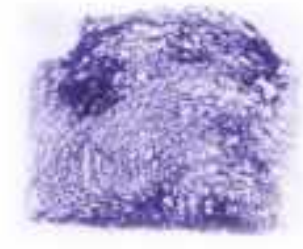

A

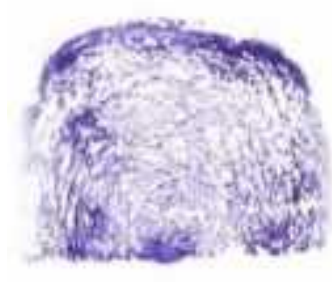

C

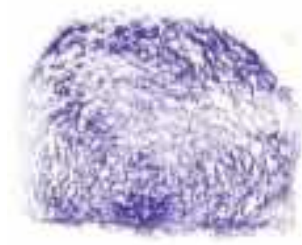

B

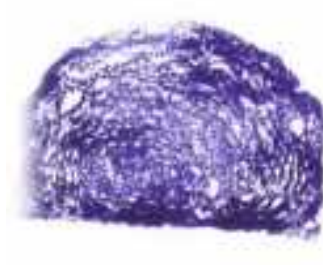

D
Gambar 3. Keseragaman Pori Roti

Dari Gambar 3, dapat dilihat bahwa semakin tinggi aktivitas $\alpha$-amilase dan glukoamilase, maka semakin tidak seragam dan besar pori-pori roti. Menurut Sultan (1986), pori-pori besar dan rongga pada roti terbentuk karena rusaknya struktur adonan selama pembentukan adonan dan pemanggangan. Penambahan $\alpha$-amilase dan glukoamilase akan mengalami proses liberasi granula pati sehingga granula pati pasta ubi ungu dan terigu lebih mengembang dan diharapkan dapat menggantikan kerja gluten dalam memerangkap gas yang terbentuk selama proses fermentasi. Bila gluten dan granula pasta ubi ungu dan terigu yang terdapat dalam adonan cukup kuat maka akan terbentuk lapisan film yang dapat menahan gas $\mathrm{CO}_{2}$ dengan baik sehingga terbentuk pori-pori yang mempunyai gelembung udara yang seragam.

Pori-pori roti yang baik adalah ukuran pori-pori yang kecil dan seragam di seluruh bagian crumb (Aurand et al., 1987). Menurut Sunandar (1994), pori-pori roti merupakan lapisan tipis yang terbentuk pada gluten yang berfungsi untuk memerangkap karbondioksida. Pori-pori terbentuk pada proses fermentasi, pada saat itu aktivitas ragi mulai meningkat, adonan mengembang, volume adonan bertambah akibat produksi gas karbondioksida oleh ragi, gluten menjadi lebih lembut dan elastis akibat pengaruh alkohol dan penurunan keasaman, dan gluten membentuk lapisan tipis yang dapat menahan gas. Menurut U.S. Wheat Associates (1981), pori-pori roti yang kurang seragam disebabkan oleh formula roti yang tidak seimbang, undermixing, overmixing, fermentasi yang kurang atau berlebihan, pemukulan adonan yang kurang merata, penggulungan adonan yang kurang baik 
pada saat panning, proof-box terlalu panas, dan over proofing.

Bila dikaitkan dengan pengembangan volume adonan dan pengembangan volume roti, substitusi tepung lain selain terigu akan menyebabkan berkurangnya persentase gluten pada adonan yang mengakibatkan berkurang jumlah karbondioksida yang dapat terperangkap. Semakin tinggi aktivitas $\alpha$-amilase dan glukoamilase dapat menyebabkan volume roti yang kurang mengembang, pori yang terlalu kecil dan rapat, terdapat pula pori yang besar di sebagian area. Penyebabnya adalah struktur yang dibentuknya tidak kokoh, hingga gas dapat keluar dari struktur awal dan bergabung dengan struktur lainnya sehingga membentuk pori yang besar.

Formula roti yang seimbang merupakan hal penting dalam menentukan keseragaman pori roti. Pori roti erat kaitannya dengan pengembangan adonan roti. Salah satu faktor yang membuat adonan kurang mengembang adalah kurangnya jumlah lemak yang ditambahkan untuk formula roti yang dibuat dengan penambahan $\alpha$-amilase dan glukoamilase. Menurut Bennion (1980), lemak dapat meningkatkan keseragaman pori, melembutkan remah, dan memudahkan pemotongan roti yang dihasilkan.

Proses saat penggulungan dan pembentukan adonan perlu diperhatikan karena pada saat itu gas harus dikeluarkan sepenuhnya dari adonan agar tidak terbentuk kantung-kantung udara yang besar. Penggulungan yang kurang sempurna memungkinkan adanya gas hasil fermentasi yang masih terperangkap, sehingga pada saat fermentasi akhir dan pemanggangan tercipta pori-pori yang besar pada roti (Sultan, 1986).

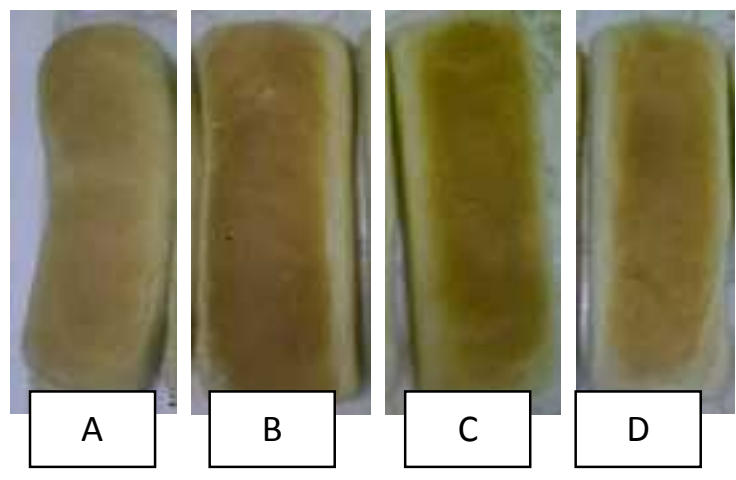

Gambar 4. Roti Perlakuan A, B, C, dan D

Dari Gambar 4 dapat dilihat bahwa semakin tinggi aktivitas $\alpha$-amilase dan glukoamilase, maka roti yang dihasilkan memiliki volume pengembangan yang semakin besar. Penambahan $\alpha$-amilase dalam tepung pada roti menyebabkan meningkatnya proses dektrinisasi (Hugo et al., 2000). Adanya $\alpha$-amilase dan glukoamilase mengakibatkan pemecahan amilosa yang menghasilkan gula-gula sederhana lebih banyak sehingga diperkirakan dapat membantu proses fermentasi gula oleh ragi. Peningkatan fermentasi gula menghasilkan gas karbondioksida yang lebih banyak mendorong roti untuk mengembang. Tetapi, pada aktivitas $\alpha$-amilase dan glukoamilase $75 \mathrm{U} / \mathrm{g}$ tepung, terlihat roti menjadi kurang mengembang. Hal ini dapat disebabkan pada saat awal proses pemanggangan terjadi penurunan viskositas adonan dan terjadi peningkatan aktivitas enzim. Ketika suhu mencapai $56^{\circ} \mathrm{C}$, maka mulai terjadi gelatinisasi pati dan memudahkan terjadinya amilolisis. Hidrolisis pati yang tergelatinisasi akan membentuk dekstrin dan gula sederhana, dan pada saat yang bersamaan terjadi pelepasan air. Amilolisis pada penambahan $\alpha$-amilase dan glukoamilase $25 \mathrm{U} / \mathrm{g}$ tepung dan $50 \mathrm{U} / \mathrm{g}$ tepung masih terbatas sehingga adonan tidak lengket dan memiliki volume pengembangan yang cukup sedangkan penambahan $\alpha$-amilase dan glukoamilase $75 \mathrm{U} / \mathrm{g}$ tepung memiliki karakteristik adonan yang agak lengket sehingga volume pengembangannya menjadi terhambat.

Menurut U.S. Wheat Associates (1981), faktor penting dalam pengembangan volume adonan adalah proses mixing. Proses mixing yang baik dapat menunjang proses pemerataan distribusi bahan pada adonan yang menyebabkan roti mengembang. Pada proses ini seluruh bahan bisa bekerja optimal di seluruh area.

\section{Volume Pengembangan Roti}

Pengaruh aktivitas $\alpha$-amilase dan glukoamilase terhadap pengembangan volume roti disajikan pada Gambar 5. Aktivitas $\alpha$-amilase dan glukoamilase $25 \mathrm{U} / \mathrm{g}$ tepung dan $50 \mathrm{U} / \mathrm{g}$ tepung terlihat volume pengembangan roti semakin besar. Hal ini diduga disebabkan adanya penambahan $\alpha$-amilase dan glukoamilase menyebabkan hidrolisis pati yang menghasilkan dekstrin dan gula-gula sederhana yang sangat diperlukan pada proses fermentasi, selain itu penambahan glukoamilase dapat meningkatkan terbentuknya glukosa yang lebih cepat dapat dimanfaatkan oleh ragi sehingga mempercepat proses fermentasi dan pengembangan adonan. Tetapi untuk penambahan $\alpha$-amilase dan glukoamilase dengan aktivitas $75 \mathrm{U} / \mathrm{g}$ tepung, volume pengembangan menurun. Hal ini dapat terjadi karena amilolisis yang terlalu intensif yang menyebabkan adonan kehilangan air dan dekstrin yang terbentuk terlalu banyak yang menyebabkan adonan menjadi lengket sehingga tidak dapat mengembang dengan baik (Antara, 2010).

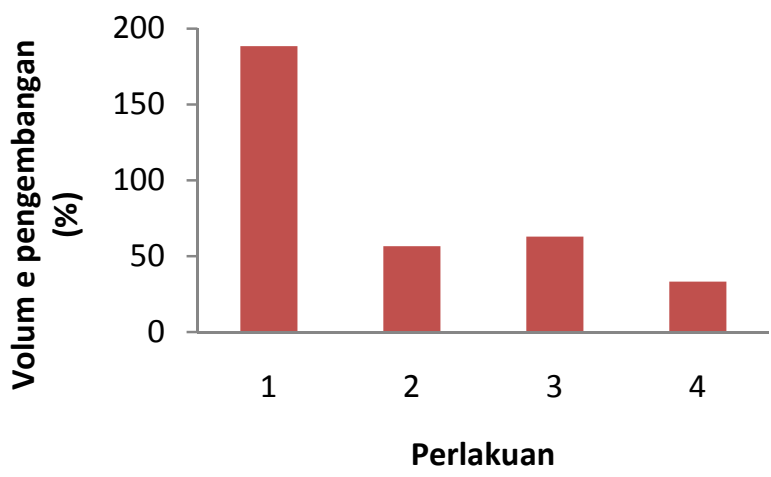

Gambar 5. Volume Pengembangan Roti (\%) 
Besar kecilnya pengembangan volume roti yang dihasilkan ditentukan oleh fermentasi yang dilakukan sebelum adonan dipanggang. Apabila selama fermentasi adonan mengembang dengan baik maka roti yang dihasilkan memiliki pengembangan volume yang besar pula. Menurut Peckham (1964), oven spring adalah peningkatan volume yang terjadi selama 10 menit pertama pada saat pemanggangan

Adanya perbedaan pengembangan volume terjadi pada saat proses pemanggangan. Pada proses pemanggangan terjadi restrukturisasi dari adonan menjadi roti yang memiliki kulit di bagian luar atau biasa disebut crust dan bagian dalam yang lebih lembut disebut crumb. Perbedaan suhu pada saat proofing dan baking cukup tinggi, adonan yang tidak memiliki struktur gluten yang kokoh yang disebabkan karena undermixing ataupun overproofing dapat mengalami penciutan (collapse) yang drastis pada saat dilakukan proses pemanggangan atau baking karena gluten tidak mempunyai kemampuan untuk menahan gas dalam adonan (U.S. Wheat Associates, 1981).

\section{Kadar Air Crumb}

Pengaruh aktivitas $\alpha$-amilase dan glukoamilase terhadap kadar air roti disajikan pada Gambar 6.Aktivitas $\alpha$-amilase dan glukoamilase dari 25 sampai $75 \mathrm{U} / \mathrm{g}$ tepung terlihat semakin tinggi kadar airnya. Hal ini berkaitan erat dengan penambahan $\alpha$-amilase dan glukoamilase akan meyebabkan hidrolisis pati yang sangat penting perannya karena sejumlah air akan diikat oleh pati yang terhidrolisis (amilosa terlarut). Hal inilah yang menyebabkan kadar air roti yang ditambahkan $\alpha$ amilase dan glukoamilase memiliki kadar air yang cukup tinggi dibandingkan dengan roti tanpa penambahan $\alpha$ amilase dan glukoamilase.

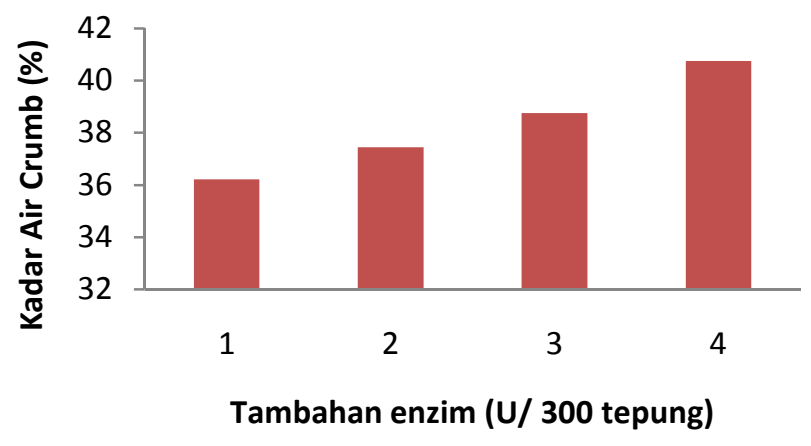

Gambar 6. Kadar Air Roti(\%)

Pomeranz \& Shellenberger (1971) menyatakan bahwa jumlah air yang ditambahkan saat pembuatan adonan tergantung dari daya serap air pada bahan yang digunakan untuk pembuatan adonan. Air yang digunakan pada pembuatan roti mempunyai fungsi yaitu membantu pembentukan gluten dan melarutkan bahan-bahan lain agar adonan dapat tercampur dengan sempurna (Wiriano, 1981).

Kadar air roti komposit ubi jalar ungu yang dihasilkan pada penelitian ini berkisar antara 36,21 -
40,76\%. Kadar air tersebut masih memenuhi syarat mutu roti menurut SNI nomor 01-3945-1998, yaitu maksimum 40\% (Badan Standardisasi Nasional, 1998).

\section{Kadar Gula Pereduksi}

Pengaruh aktivitas $\alpha$-amilase dan glukoamilase terhadap kadar gula pereduksi roti disajikan pada Gambar 7.Selama proses fermentasi, sebelum khamir merombak gula menjadi alkohol dan karbondioksida, karbohidrat yang tersedia mengalami perombakan menjadi jenis gula sederhana. Buckle et. al.(1987) menyatakan bahwa karbohidrat terbanyak yaitu tepung roti diubah menjadi maltosa oleh enzim amilase yang ada pada tepung. Sukrosa diubah menjadi glukosa dan fruktosa oleh enzim invertase. Molekul maltosa, dengan bantuan enzim khamir maltase, terhidrolisis menjadi dua molekul glukosa. Selanjutnya kompleks enzim zimase dari enzimenzim khamir menguraikan molekul glukosa atau fruktosa menjadi alkohol dan karbondioksida (Stear, 1990).

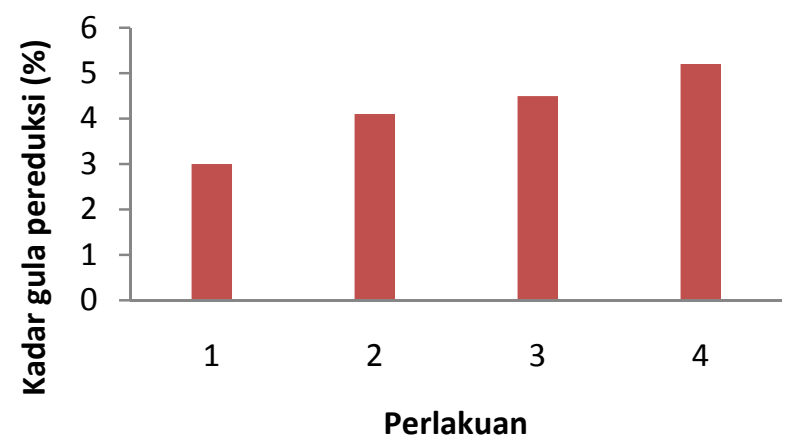

Gambar 7. Kadar Gula Pereduksi Roti(\%)

Kadar gula pereduksi dari roti ini berkisar antara $3,00 \%$ - 5,20\%, hal ini diduga karena laju reaksi perombakan karbohidrat menjadi gula sederhana tidak lebih cepat dibanding laju perombakan gula sederhana menjadi alkohol dan karbondioksida oleh khamir. Hal ini memungkinkan tidak terjadinya akumulasi gula pereduksi pada roti.

Sultan (1986) menyatakan bahwa reaksi konversi sukrosa menjadi gula sederhana jauh lebih cepat dibanding penggunaannya oleh khamir, akan tetapi hal ini hanya terjadi di awal fermentasi dengan jumlah sukrosa yang sangat terbatas. Pada proses selanjutnya setelah sukrosa habis dan jumlah sel khamir lebih banyak memungkinkan laju perombakan gula sederhana menjadi alkohol dan karbondioksida lebih cepat.

\section{Kekerasan Roti Bagian Crumb}

Salah satu parameter mutu roti yang baik adalah tekstur crumb yang empuk. Pengaruh aktivitas $\alpha$-amilase dan glukoamilase terhadap kekerasan bagian remah roti disajikan pada Gambar 8.Penambahan $\alpha$-amilase dan glukoamilase menyebabkan roti menjadi empuk, terlihat dari data bahwa roti tanpa penambahan $\alpha$-amilase dan glukoamilase memiliki tingkat kekerasan yang cukup tinggi dibandingkan dengan yang lainnya. Hal ini dapat 
disebabkan penambahan $\alpha$-amilase dan glukoamilase akan menghasilkan dekstrin dan gula-gula sederhana yang dibutuhkan oleh ragi untuk merombak gula-gula tersebut menjadi alkohol dan $\mathrm{CO}_{2}$.

Substitusi terigu oleh sorgum akan menghasilkan pengurangan keempukan roti akibat dari kadar gluten yang berkurang dan diperlukannya penambahan jumlah lemak agar roti yang dihasilkan memiliki keempukan yang baik.

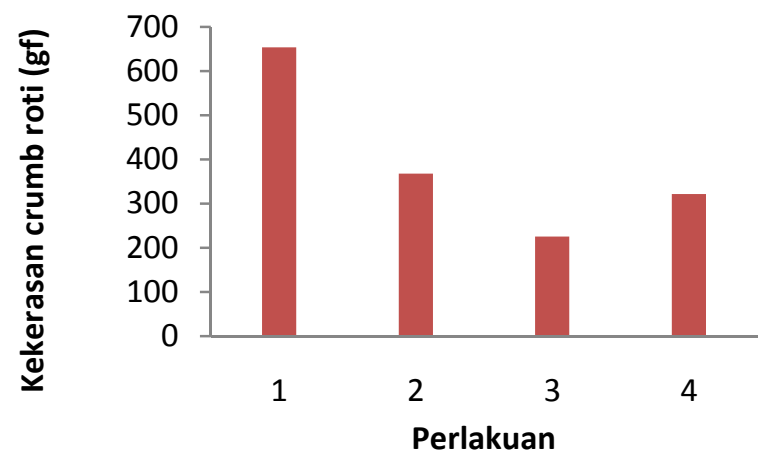

Gambar 8. Kekerasan Bagian Remah Roti

\section{Simpulan}

Aktivitas optimum $\alpha$-amilase dan glukoamilase dari ragi $S$. Fibuligeraadalah $50 \mathrm{U} / 300 \mathrm{~g}$ tepung, menghasilkan volume pengembangan 63\%;kadar air 39\%; kadar gula pereduksi $4,5 \%$ dan kekerasan crumb 225,52 gf. Roti komposit yang dihasilkanmempunyai volume pengembangan yang masih rendah jika dibandingkan dengan roti control (100\% terigu) namun memiliki kadar air dan kadar gula reduksi lebih tinggi dari roti control sehingga roti komposit mempunyai tingkat keempukkan hamper sama dengan roti kontrol.

\section{Daftar Pustaka}

Ahza, A.B. 1998. Aspek Pengetahuan Material dan Diversifikasi Produk Sorgum sebagai Substitutor Terigu/Pangan Alternatif. Dalam Laporan Lokakarya Sehari Prospek Sorgum sebagai Bahan Substitusi Terigu. PT. ISM Bogasari Flour Mills, Jakarta.

Antara, N.S. 2010. Meningkatkan Mutu Roti dengan Penambahan Enzim. Food Review Edisi Mei 2010. Jakarta.

Aurand, L. W, A.E. Woods \& M. R. Wells. 1987. Food Composition and Analysis. Van Nostrand Reinhold, New York, NY.

Badan Standardisasi Nasional. 2000. Tepung Terigu Sebagai Bahan Makanan. SNI 01-3751-2000. Jakarta.

Bennion, M. 1980. The Science of Food. John Wiley \& Sons, Inc., New York, NY.

Buckle, K.A, R.A. Edwards, G.H. Fleet dan M. Wooton. 1992. Ilmu Pangan. UI Press, Jakarta.

Caballero, P.A., M. Gomez \& C.M. Rosell. 2007. Improvement of Dough Rheology, Bread Quality and Bread Shelf-Life by Enzymes Combination. Journal of Food Engineering $81:$ 42-53.

Goesaert, H., Slade, L., Levine, H., \& Declour, J.A. 2009. Amylases and bread firming-an integrated view. Journal of Cereal Science. 50:345-52.

Gray, J.A. \& J.N. BeMiller. 2003. Bread staling: Molecular basis and control. Comprehensive Reviews in Food Science and Food Safety, 2: 1-20.

Hostinova, E. 2002. Amylolytic enzymes produced by the yeast Saccharomycopsis fibuligera. Biologia, Bratislava, 57/Suppl. 11: 247-251.

Hugo, L.F., Rooney, L.W. \& Taylor, R.N. 2000. Malted Sorghum as Functional Ingredient in Composite Bread. Cereal Chemistry. 77(4):428-432.

Hulse, J. H., E. N. Laing \& O.E. Pearson. 1980. Sorgum and Millets : Their Composition And Nutrition Value. Academic Press, London.

Lange, M \& Bogasari Baking Centre. 2004. Roti : Teori dan Resep International. Bogasari Baking Centre, Jakarta.

Marlon. 1994. Pengaruh Penambahan Natrium Alginat Pada Substitusi Parsial Tepung Terigu Dengan Tepung Campuran Serta Aplikasinya Dalam Pembuatan Roti Tawar. Skripsi S1. Fakultas Teknologi Pertanian IPB, Bogor.

Peckham, G. B. 1964. Foundations of Food Preparation. The Macmillan Company, New York, NY.

Pomeranz,Y. \& J.A. Shellenberger, 1971. Bread Science and Technology. AVI. Westport. Coneccticut.

Stear, C.A. 1990. Handbook of Bread making Technology. Elsevier Applied Science. London and New York.

Sultan, W.J. 1986. Practical Baking. Van Nostrand Reinhold, New York, N Y.

Sunandar, R. 1994. Subtitusi Parsial Tepung Terigu dan Penambahan Potasium Bromat Dalam Pembuatan Roti Tawar. Skripsi S1. Fakultas Teknologi Pertanian IPB, Bogor.

U.S. Wheat Associates. 1981. Pedoman Pembuatan Roti dan Kue. Djambatan, Jakarta.

Wikipedia. 2008. Roti. Available online at : http://ms.wikipedia.org/wiki/Roti (20 Januari 2008)

Wiriano, H. 1981. Diktat Pembuatan Roti. Balai Besar Industri Hasil Pertanian, Bogor. 